\title{
Effectiveness of Olive Fruit Polyphenol Extract Combined with Aqueous Extracts of Solid Wastes of Pomegranate or/ and Orange Juice Against Important Plant Pathogens - Part 2 (in vivo studies)
}

\author{
Stefanos Leontopoulos ${ }^{*}$, Konstantinos Petrotos, Chryssoula Papaioannou, Ioannis Vasilakoglou \\ Department of Agriculture-Agrotechnology, Laboratory of Food and Biosystems Engineering, University of Thessaly, \\ Geopolis of Larissa, 41500, Greece
}

Received November 9, 2020; Revised December 22, 2020; Accepted January 20, 2021

\section{Cite This Paper in the following Citation Styles}

(a): [1] Stefanos Leontopoulos, Konstantinos Petrotos, Chryssoula Papaioannou, Ioannis Vasilakoglou, "Effectiveness of Olive Fruit Polyphenol Extract Combined with Aqueous Extracts of Solid Wastes of Pomegranate or/ and Orange Juice Against Important Plant Pathogens - Part 2 (in vivo studies), " Universal Journal of Agricultural Research, Vol. 9, No. 2, pp. 23-38, 2021. DOI: 10.13189/ujar.2021.090201.

(b): Stefanos Leontopoulos, Konstantinos Petrotos, Chryssoula Papaioannou, Ioannis Vasilakoglou (2021). Effectiveness of Olive Fruit Polyphenol Extract Combined with Aqueous Extracts of Solid Wastes of Pomegranate or/ and Orange Juice Against Important Plant Pathogens - Part 2 (in vivo studies). Universal Journal of Agricultural Research, 9(2), 23-38. DOI: 10.13189/ujar.2021.090201.

Copyright $\odot 2021$ by authors, all rights reserved. Authors agree that this article remains permanently open access under the terms of the Creative Commons Attribution License 4.0 International License

\begin{abstract}
Olive fruit extracts, combined with pomegranate and orange waste extracts, isolated using microwave assisted extraction technique, were used as a potential alternative crop protection method against Verticillium dahliae, Rhizoctonia solani, Botrytis cinerea and Pyrenochaeta lycopersici on tomato plants. For the evaluation of the antimicrobial activity, various mixtures of the extracts were applied on 15 days old tomato plants, variety "Bella Dona", infected by the above-mentioned pathogens. After 40 days of treatments, plant growth parameters such as plant fresh and dry weight, root weight, plant height, number of blossoms and number of formed fruits were calculated in order to assess the extract effectiveness. The results indicated that the four pathogens dramatically reduced tomato growth. In contrast, most of the evaluated extracts provided satisfactory control of the pathogens resulting in tomato growth similar to that of the uninfected control plants. Conclusively, the use of these polyphenolic extracts could protect tomato plants in case of fungal infection.
\end{abstract}

Keywords Polyphenols, Pomegranate, Orange, Olive Fruit Extracts, Biocontrol, Plant Diseases, Tomato Plants

\section{Introduction}

A significant increase in food supply is needed due to the emerging global growing population which is estimated to reach 9.7 billion by 2050 [1]. Crop losses from pests and diseases, it is estimated to range from 17 to $30 \%$ worldwide [2]. Furthermore, the use of several plant species for energy production may limit fatherly crop areas cultivated for food production purposes [3-7].

Despite all actions aimed to sustainable agriculture, environmental problems are increasing due to the increasing use of agrochemicals and the high amount of the produced wastes and heavy metals resulting in adverse effects on human health affecting as well environment quality and food-chain [8-14]. Therefore, it is necessary to seek for alternatives of agrochemical products and take further action to explore the potential of agricultural wastes [15]. These actions reflect the ever-increasing interest in maximizing the use of agricultural by-products for various purposes [16]. In recent years, there has been 
significant interest in linking waste management and use of more environmental friendly crop protection products. Thus, several research studies are focused on using these wastes and natural compounds in innovative applications [17-27]. Plant tissues as well as fruit residues after proper treatment have been found to be effective against several human diseases due to the anti-inflammatory, antioxidant and antimicrobial properties [28-42]. In order to extract efficiently these bioactive compounds, many methods have been proposed [43-49]. This study is in continues to previous in vitro study where it was proved that the use of $100 \%$-pure olive fruit polyphenol extract affected the mycelium growth of $B$. cinerea, $V$. dahliae, $R$. solani and $P$. lycopersici, while, pomegranate polyphenol extract at $100 \%$ concentration inhibited mycelium growth of $B$. cinerea suggested that various olive-pomegranate-orange polyphenol aqueous extract combinations may be used in order to control the mycelium growth of the majority of the tested microorganisms. The aim of the research study was the evaluation of mixed liquid extracts of olive, pomegranate and orange wastes used as natural phytoprotective agents in organic farming. The assessment of different concentrations and mixtures of polyphenols from olive oil wastes-orange and pomegranate as plant protection materials against economically important plant pathogenic fungi in in vivo tests was the main research area of this research work. Tomato plant growth used in order to assess the effectiveness of these polyphenolic mixtures against 4 important fungal pathogens.

\section{Materials and Methods}

\subsection{General}

Agricultural wastes by three plant species were examined for their antimicrobial potential activity in an in vivo study. These wastes were aqueous microwave assisted isolates extracted by olive fruit, pomegranate and orange peels.

The in vivo antimicrobial activity of polyphenols was evaluated against $V$. dahliae, $B$. cinerea, $R$. solani and $P$. lycopersici.. All fungal microorganisms used in this study were obtained from the Benaki Phytopathological Institute (B.F.I.) in Athens Greece. The plant pathogens, their code and the source of collection are listed in the following Table 1.

Table 1. Tested fungal species for the in vivo experiments

\begin{tabular}{ccc}
\hline Fungal pathogen & Code & Source of Collection \\
\hline Verticillium dahliae & 2509 & B.F.I. \\
Botrytis cinerea & 1948 & B.F.I. \\
$\begin{array}{c}\text { Pyrenochaeta } \\
\text { lycopersici }\end{array}$ & 2587 & B.F.I. \\
Rhizoctonia solani & 2531 & B.F.I. \\
\hline
\end{tabular}

B.F.I.: Benaki Phytopathological Institute, Greece
The potential antimicrobial activity of liquid olive fruit polyphenol extract with aqueous extracts of solid wastes of pomegranate or/and orange juice industry against fungal phytopathogenic species were examined in previous in vitro research study where results showed that the use of olive fruit and pomegranate polyphenol extract affected the mycelium growth of $B$. cinerea, $V$. dahliae, $R$. solani and P. lycopersici [50]. The concentrations and combinations of liquid olive fruit pomegranate and orange extracts used were as follows in Table 2.

Table 2. Ratios of olive, pomegranate and orange polyphenol extracts

\begin{tabular}{cccc}
\hline $\begin{array}{c}\text { Number of } \\
\text { sample }\end{array}$ & $\begin{array}{c}\text { Olive fruit } \\
(\%)\end{array}$ & $\begin{array}{c}\text { Pomegranate } \\
(\%)\end{array}$ & $\begin{array}{c}\text { Orange } \\
(\%)\end{array}$ \\
\hline $\mathbf{1 1}$ & 80 & - & 20 \\
$\mathbf{2 8}$ & 90 & 7 & 3 \\
$\mathbf{3 4}$ & 50 & 25 & 25 \\
$\mathbf{3 7}$ & 80 & 10 & 10 \\
$\mathbf{3 8}$ & 90 & 5 & 5 \\
$\mathbf{4 7}$ & 80 & 6 & 14 \\
$\mathbf{5 7}$ & 80 & 12 & 8 \\
$\mathbf{5 8}$ & 90 & 6 & 4 \\
$\mathbf{6 7}$ & 80 & 8 & 12 \\
$\mathbf{6 8}$ & 90 & 4 & 6 \\
$\mathbf{7 0}$ & 100 & - & - \\
\hline
\end{tabular}

Subsequently, the liquid solutions were placed in sterile commercial plastic containers, numbered accordingly and kept in frozen at $-23.3^{\circ} \mathrm{C}$. Whenever needed a small amount of the samples were used in order to examine their antifungal activity against important plant pathogenic microorganisms in vivo. The phytopathogenic fungi were grown in Petri dishes filled with PDA and kept at $4^{\circ} \mathrm{C}$,

\subsection{Preparation of Plants-Inoculums Application}

As mentioned above 15 days old tomato plant, variety "Bella Dona" were used to ascertain the effectiveness of the antimicrobial activity of different concentrations and combinations of the examined polyphenolic compounds against 4 important fungal pathogens on tomato plants. The possible phytotoxic effects of these extracts were also evaluated. The method followed was described in previous work completed by Leontopoulos et al., [50-52]. More specific the tomato plants were transplanted in disposable plastic pots $(19 \times 18 \mathrm{~cm})$ which were filled with a mixture of high peat Potgrad P, suitable for propagation of horticultural seedling obtained from Company Klassman-Dolmann GmbH Germany as imported in Greek market from AGROCHOUM SA with $\mathrm{pH}$ : 5,5-6,5; EC: $45 \mathrm{mS} / \mathrm{m}$ and organic matter: $90-95 \%$. Temperature in glasshouse varied from $22-27^{\circ} \mathrm{C}$ according to the electronic thermometer located in the greenhouse. Light could not be measured. However, light duration was the standard one observed in Greece during April and at the end of August. Humidity was varied from $65-77 \%$. The irrigation type was drip irrigation with drips made to each 
pot. The transplanted plants were watered in order to avoid dryness. The application of different concentrations-combinations of the examined extracts was applied after two days of transplanting. After $24 \mathrm{hrs}$ of the extract application, a hole near the root system was made in order to apply $2 \mathrm{ml}$ of fungal spore suspension for the plant infection. Similar amount $(2 \mathrm{ml})$ of the examined polyphenolic extract was also applied in order to evaluate their effectiveness in plant growth and fungus action. Plant controls (plants without infestation or extract) were not infected and did not receive extract. Finally, chemical controls were used to which only extract was applied, in order to evaluate a possible phytotoxic effect. In case of application of $B$. cinerea a spore suspension was sprayed on the plants. The same treatment was followed for extract's application in plant leaves using a sprayer. Then, the plants were placed in greenhouse and were irrigated when needed. Four plants were used in each treatment and the experiment was repeated twice. After 40 days of application, plants were harvested and fresh and dry plant weight, fresh and dry root weight, plant height, number of blossoms and number of tomato fruits was measured. For the determination of dry root and plant weigh the tomato plants were placed on paper bags and drying at $80{ }^{\circ} \mathrm{C}$ for 48 hours.

\subsection{Statistical Analysis}

A randomized complete block experiment design was selected for the study. Data are expressed as the means of 4 measurements. Statistical differences among the mean values were detected by ANOVA. Dunkan's test was used in order to group the examined samples at 0.05 level. SPSS software was used as a tool to perform the statistical analyses. The experiment was repeated twice.

\section{Results}

In this experimental work the activity of various concentrations and mixtures of polyphenolic compounds of olive mill orange and pomegranate wastes were tested against important phytopathogenic fungi. Stem, leaves fresh weight, plant height, number of blossoms and tomato fruits were measured in order to consider the most suitable polyphenolic mixture and the possible phytotoxic effect on tomato plants "Bella Dona" variety. However, in vivo results could differ from cultivation reality in both in terms of effectiveness as well as application form, since it is still difficult to implement the polyphenolic compound as it is, in large scale in field or in greenhouse cultivations.

\subsection{In vivo Evaluation of Polyphenolic Compounds on Tomato Growth Inoculated with $P$. lycopersici}

From Figure 1A, average height of tomato plants infected with the fungus $P$. lycopersici and different concentrations of olive-pomegranate-orange polyphenolic extracts (OPO-PE), differed statistically from the average height of tomato plants where no infection was applied (control-pathogen). In more details treatments in which the average height of the tomato plants did not differ statistically between them and the treatment of "control-plant" were containing polyphenolic extracts of olive-pomegranate-orange in concentrations: 50-25-25, $80-10-10,90-5-5,80-6-14,80-12-8,90-6-4,90-4-6$ and 100-0-0. Average height of the "control-plant" treatment differed statistically important from the average height of tomato plants treated with 80-0-20, 90-7-3, 80-8-12 olive-pomegranate-orange concentrations, as well as from the average height of the tomato plants infested with $P$. lycopersici only (control-pathogen).

Regarding, the evaluation of the results of Figure 1B, it was observed that the average fresh weight of the tomato plants used as "control-plant" did not differ statistically from the average fresh weight of the tomato plants treated with OPO-PE at 80-0-20, 80-10-10, 90-5-5, 80-6-14, $80-12-8,90-6-4,90-4-6$ and 100-0-0\%. However, average fresh weight of the "control-plant" treatment differed statistically important from the average fresh weight of the OPO-PE at: $90-7-3,50-25-25,80-8-12 \%$, as well as from the average fresh weight of the "control-pathogen" treatment. Although, average fresh weight of the tomato plants in treatments containing OPO-PE at concentrations of $90-5-5$ and $100-0-0 \%$, were slightly higher even from those observed in the "control-plant" treatment.

The presence of the pathogen caused a reduction of the dry weight of the aboveground part of the tomato plants by more than $50 \%$ (Figure 1C). On the contrary, in the tomato plants where simultaneously applied the extracts $80 / 10 / 10,90 / 5 / 5,80 / 8 / 12$ and $100 / 0 / 0$, there was no significant reduction of the dry aboveground weight of the crop. However, limited reduction in dry plant weight was observed on the rest of the treatments.

Regarding dry root weight it was observed that $P$. lycopersici affected root growth of tomato plants inoculated only with the phytopathogenic fungus (Figure 1d). In contrast, in the infected plants where the extracts were applied, the root weight was not negatively affected or it was slightly (treatments $80 / 10 / 10,80 / 6 / 14$ and 90/4/6).

Due to the large variability among observed data, average number of tomato flowers did not differ statistically between the treatments applied except one treatment (Figure 1E). It is worth mentioning that the number of flowers in treatment containing OPO-PE at concentration of $50-25-25 \%$ was the largest and differed statistically significant from the treatments of OPO-PE at concentration of 90-7-3, 90-6-4\% and from the treatment in which the phytopathogenic fungus was applied.

Regarding the average number of tomato fruits formed, it was observed that there was no statistically significant difference between treatments of the polyphenolic 
substances and the control-plant (Figure 1F). A statistically significant difference was observed only on the tomato plants to which the phytopathogenic fungus was applied (control-pathogen).

Therefore, it is believed that polyphenolic extracts can limit the growth of $P$. lycopersici on tomato plants and significantly reduce the losses caused by the presence of the pathogen in this crop. Thus, the use of polyphenolic extracts it is recommended as alternative bio-chemical compound in order to reduce $P$. lycopersici infection on tomato plants as it affect the phytopathogenic microorganism and improve and maintain fresh weight and height of the infected tomato plants compared to the untreated plants.
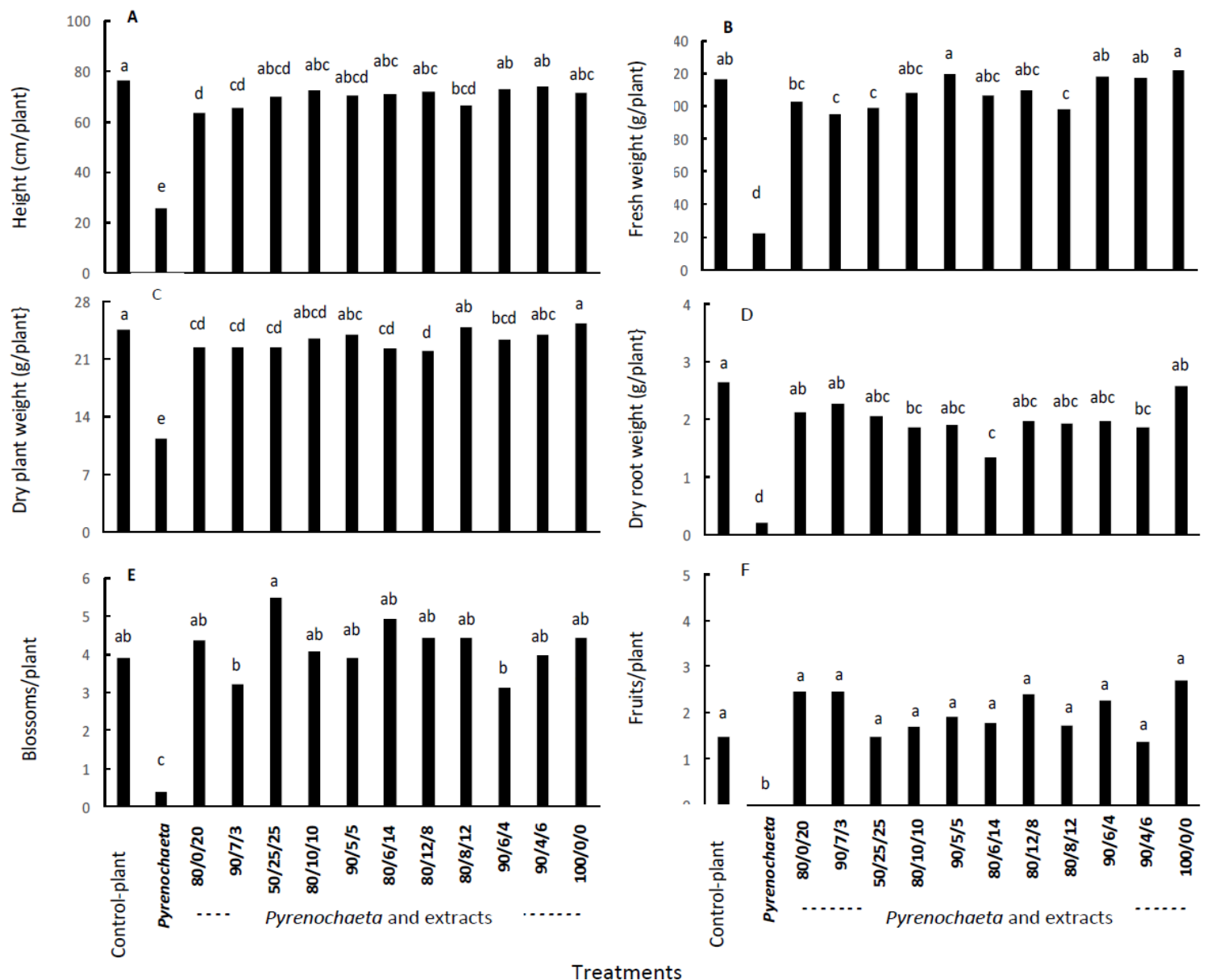

Figure 1. Fresh and dry plant and root weight, plant height, number of flowers and fruits of tomato plants infected with the fungus $P$. lycopersici to which different concentrations of olive-pomegranate-orange polyphenolic extracts were applied 


\subsection{In vivo Evaluation of Polyphenolic Compounds on Tomato Growth Inoculated with Rhizoctonia solani}

Figure 2A represents the average height of tomato plants infected with the fungus $R$. solani, to which different concentrations of olive-pomegranate-orange polyphenolic extracts have been applied. Tomato plants of the treatment "control-plant" (in which no infection or extracts were applied) grown in height, differing statistically important from the tomato plants to which the infection had been applied (control-pathogen). Tomato plants in treatment where $80 \%$ olive- $6 \%$ pomegranate- $14 \%$ orange was applied showed the highest growth in terms of height, but did not differ statistically from the tomato plants of the "control-plant" treatment. Moreover, there was no statistically important difference between the "control-plant" treatment and the treatments containing polyphenolic extracts in combination of oil-pomegranate-orange at concentrations (\%) of 50-25-25, $80-12-8,90-7-3,80-10-10,90-5-5,80-8-12,90-6-4$ and 90-4-6. However, average height of tomato plants in treatments containing polyphenolic extracts at concentrations (\%) 80-0-20 and 100-0-0 differed statistically from the average height observed in "control-plant" treatment as well as on tomato plant treatment that infection of the phytopathogenic fungus was applied.

Regarding fresh weight, Figure $2 \mathrm{~B}$ represents that average fresh weight of tomato plants, to which neither concentration of polyphenolic extracts of olive-pomegranate-orange nor the fungus $R$. solani was applied, differed significantly from the average fresh weight of the infected plants, to which polyphenolic solution at a rate of 80-0-20, 50-25-25, 80-10-10, 90-5-5, 80-10-10, 90- 5-5, 80-6-14, 80-12-8, 80-8-12, 90-6-4, 90-4-6 and 100-0-0 were applied. Although they did not differ statistically important from the "control-plant" treatment, tomato plants treated with OPO-PE at a concentration of $80 \%$ olive- $6 \%$ pomegranate- $14 \%$ orange showed the highest biomass production. In contrast, treatment containing OPO-PE at a concentration of
90-7-3\% differed statistically important from the treatment "control-plant" as well as from the tomato plants infected by the phytopathogenic fungus.

The presence of the pathogen caused a reduction of the dry weight of the aboveground part of the tomato plants by more than $50 \%$ Figure $2 \mathrm{C}$ ). On the contrary, on the tomato plants that were also applied the extracts $80 / 0 / 20$, $80 / 10 / 10,80 / 6 / 14,80 / 12 / 8,80 / 8 / 12,90 / 6 / 4,90 / 4 / 6$ and $100 / 0 / 0$ there was no significant reduction in dry ground weight of the crop. However, limited reduction in dry plant weight was observed on the rest of the treatments.

Regarding dry root weight it was observed that $R$. solani affected root growth of tomato plants inoculated only with the phytopathogenic fungus (Figure 2D). In contrast, in infected plants to which the extracts were applied the root weight was not adversely affected or it was slightly affected (50/25/25 treatment).

Regarding the evaluation of the tested polyphenolic extracts in average number of blossoms formed/tomato plant, due to the large variability of the blossoms, no statistically significant differences were observed between examined treatments (Figure 2E). However, average number of blossoms in treatment with OPO-PE, at a concentration of $80-6-14 \%$ was slightly higher than all others; it was also differed statistically important from treatments of OPO-PE, at a concentration of 80-0-20 and $80-8-12$, as well as from the "control-pathogen" treatment.

Likewise, average number of tomato fruits formed did not differ statistically important among examined treatments due to the large variability (Figure 2F). Application of OPO-PE at concentration of $80-6-14 \%$ represents quite promising results in terms of the growth of tomato plants (average height and average fresh weight). In addition, treatment of OPO-PE at concentration of $80-12-8 \%$, showed also quite promising results.

Therefore, these extracts could be applied in order to control infection of $R$. solani on tomato plants, since it was proved that they can reduce the adverse effect of the phytopathogenic microorganism affecting tomato plant growth. 


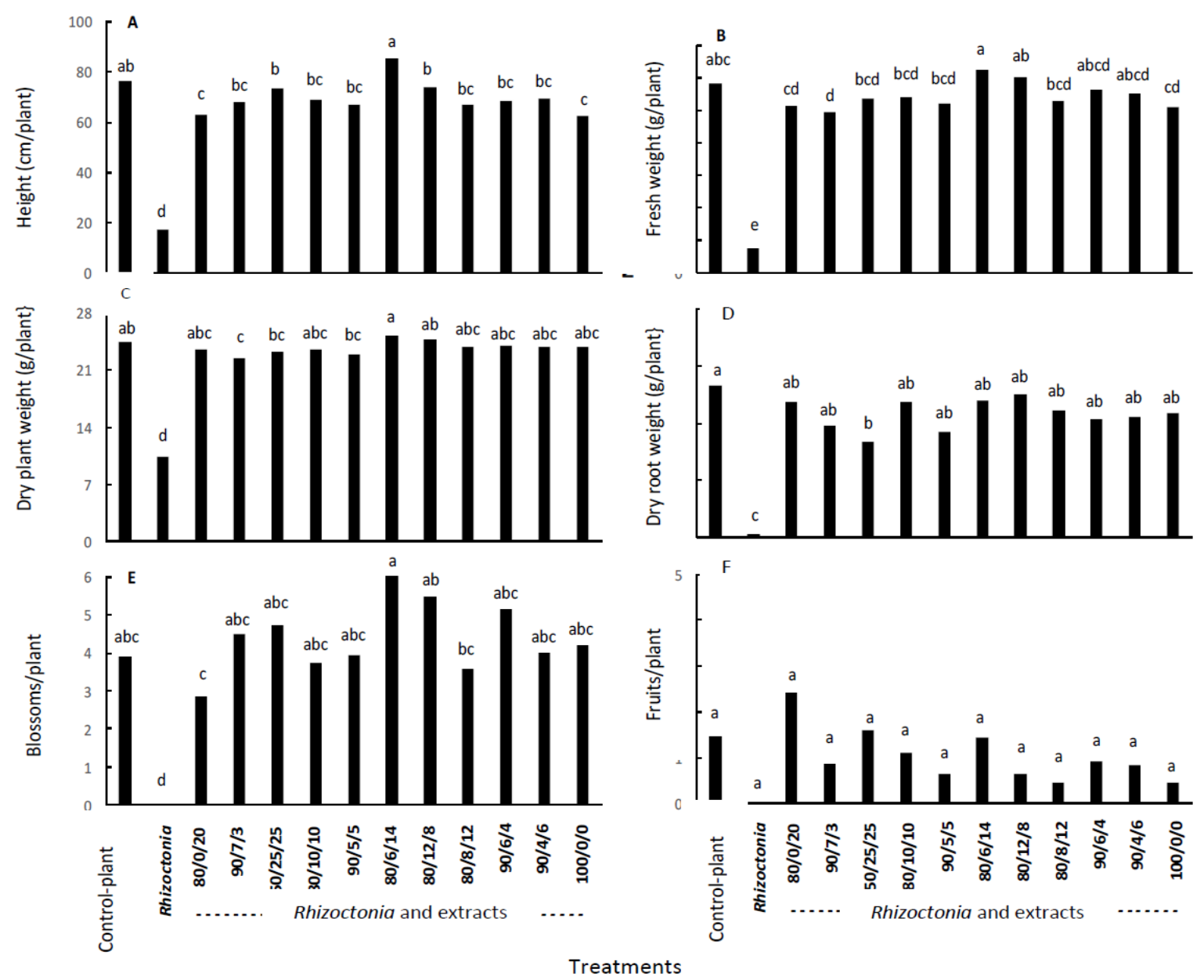

Figure 2. Fresh and dry plant and root weight, plant height, number of flowers and fruits of tomato plants infected with the fungus $R$. solani to which different concentrations of olive-pomegranate-orange polyphenolic extracts were applied.

\subsection{In vivo Evaluation of Polyphenolic Compounds on Tomato Growth Inoculated with Verticillium dahliae}

Figure 3A represents average height of tomato plants infected with the fungus $V$. dahliae, in which different concentrations of OPO-PE have been applied. The results showed that average height of tomato plants that had not been treated (control-plant) differed statistically important from the average height of infected with the pathogen $(V$. dahliae) plants. This treatment was also differed statistically important from the treatment where OPO-PE, at a concentration of $80-0-20 \%$ was applied. In more details, average plant height of the treatments where OPO-PE, applied at a concentration of 90-7-3, 50-25-25, 80-10-10, 90-5- 5, 80-6-14, 80-12-8, 90-6-4, 90-4-6 and $100-0-0$ did not differ statistically important from the treatment where no application was applied. Average height of OPO-PE treatment of $90-4-6 \%$ was slightly higher even than the average height observed in the treatment of the "control-plant".

Figure 3B represents average fresh weights of tomato plants infected with the fungus $V$. dahliae. The results have shown that the fresh weight of the treatment "control-plant" did not differ statistically important from the average fresh weights of the tomato plants treated with OPO-PE, at a concentration of 90-7-3, 50-25-25, 80-10-10, $90-5-5,80-6-14,80-12-8,90-6-4,90-4-6$ and $100-0-0 \%$. However, average weigh of fresh tomato plants in treatment "control plants" differed statistically from the average fresh weight of the OPO-PE, at a concentration of $80-0-20$, as well as from the average fresh weight of the treatment infected with the plant pathogenenic fungus. Average fresh weight of tomato plants treated with OPO-PE, at a concentration of 90-4-6 was slightly higher even than the average fresh weight observed on the "control-plant" treatment.

The presence of the pathogen caused a reduction of the dry weight of the aboveground part of the tomato plants by more than $50 \%$ (Figure 3C). In contrast, in tomato plants where applied almost all of the extracts at the same time, no significant reduction in the dry ground weight of the crop was observed. However, a slight decrease in dry weight was observed in the extractions of the extracts $80 / 0 / 20$ and $80 / 6 / 14$. 
Regarding dry root weight, it was observed that $V$. dahliae affected root growth of tomato plants inoculated only with the phytopathogenic fungus (Figure 3D). In contrast, in the infected tomato plants where OPO-PE treatment containing the $90 / 6 / 4,90 / 4 / 6$ and $100 / 0 / 0 \%$ were applied, the weight of dry roots was not negatively affected. However, in the infected plants to which the remaining extracts were applied, the weight of the tomato roots showed an intermediate decrease, relative to the root weight of the tomato plants used as control.

Regarding the number of blossoms formed on tomato plants, due to the large variability of formed blossoms, there was no statistically important difference among the examined treatments beside the treatment where the plant pathogen was applied (Figure 3E). Number of flowers in OPO-PE treatment containing $50-25-25$ and $80-12-8 \%$ was higher than the rest and differed statistically important from the treatments containing OPO-PE at a concentration of 80-6-14, 90-6-4, 80-0-20, as well as the treatment where "control-pathogen" was applied. Likewise, due to the large variability in number of formed tomato fruits/plant, it was observed no statistically significant difference among the examined treatments (Figure 3F).

Therefore, the use of polyphenolic extracts can be used in order to treat tomato plants infected by $V$. dahliae, as these extracts limit the growth of the fungus, resulting a satisfactory plant growth.
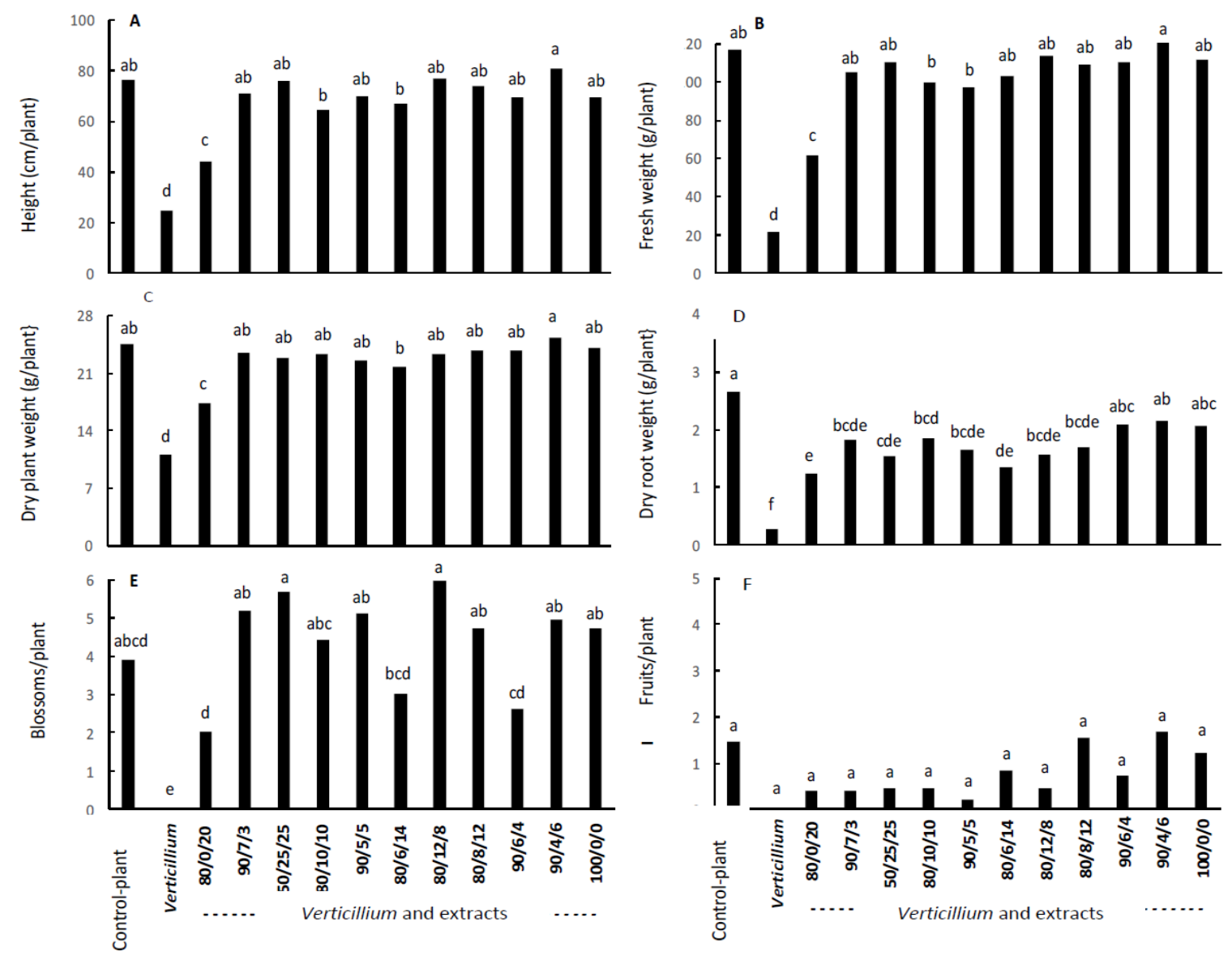

Treatments

Figure 3. Fresh and dry plant and root weight, plant height, number of flowers and fruits of tomato plants infected with the fungus $V$. dahliae to which different concentrations of olive-pomegranate-orange polyphenolic extracts were applied. 


\subsection{In vivo Evaluation of Polyphenolic Compounds on Tomato Growth Inoculated with Botrytis cinerea}

Figure 4A represents average height of tomato plants infected with the fungus $B$. cinerea, in which different concentrations of OPO-PE have been applied. The results showed that average height of tomato plants that had not been treated (control-plant) differed statistically important from the average height of infected with the pathogen $(B$. cinerea) plants. In more details, average plant height of the treatments where OPO-PE, applied at a concentration of 80-0-20, 90-7-3, 50-25-25, 80-10-10, 90-5-5, 80-6-14, 80-12- 8, 90-6-4, 90-4-6 and 100-0-0 did not differ statistically important from the treatment where no application was applied. Average height of OPO-PE treatment of $80-12-8$ and $80-6-14$ were slightly higher even than the average height observed in the treatment of the "control-plant".

Figure 4B represents the average fresh weights of tomato plants infected with the fungus $B$. cinerea. The results have shown that the fresh weight of the treatment "control-plant" did not differ statistically important from the average fresh weights of the tomato plants treated with
OPO-PE, at a concentration of 80-0-20, 90-7-3, 50 -25-25, 80-10-10, 90-5-5, 80-6-14, 80-12-8, 90-6-4, 90-4-6 and $100-0-0 \%$. However, average weigh of fresh tomato plants in treatment "control plants" differed statistically from the average fresh weight of the treatment infected with the plant pathogenenic fungus. Average fresh weight of tomato plants treated with OPO-PE, at a concentration of 80-12-8 was slightly higher even than the average fresh weight observed on the "control-plant" treatment.

The presence of the pathogen caused a reduction in the dry weight of the aboveground part of the tomato plants by $27 \%$ (Figure $4 \mathrm{C}$ ). In contrast, in the tomato plants where the extracts were applied at the same time, no significant reduction in the dry plant weight of the crop was observed.

The pathogen infestation caused an important reduction in the weight of the root system in treatment where $B$. cinerea was applied as control (Figure 4D). In contrast, in the infected tomato plants where the tested extracts were applied, dry root weight was not affected or it was affected slightly (treatments with extracts 50/25/25, 90/5/5, $80 / 6 / 14,80 / 12 / 8$ and 90/6/4).
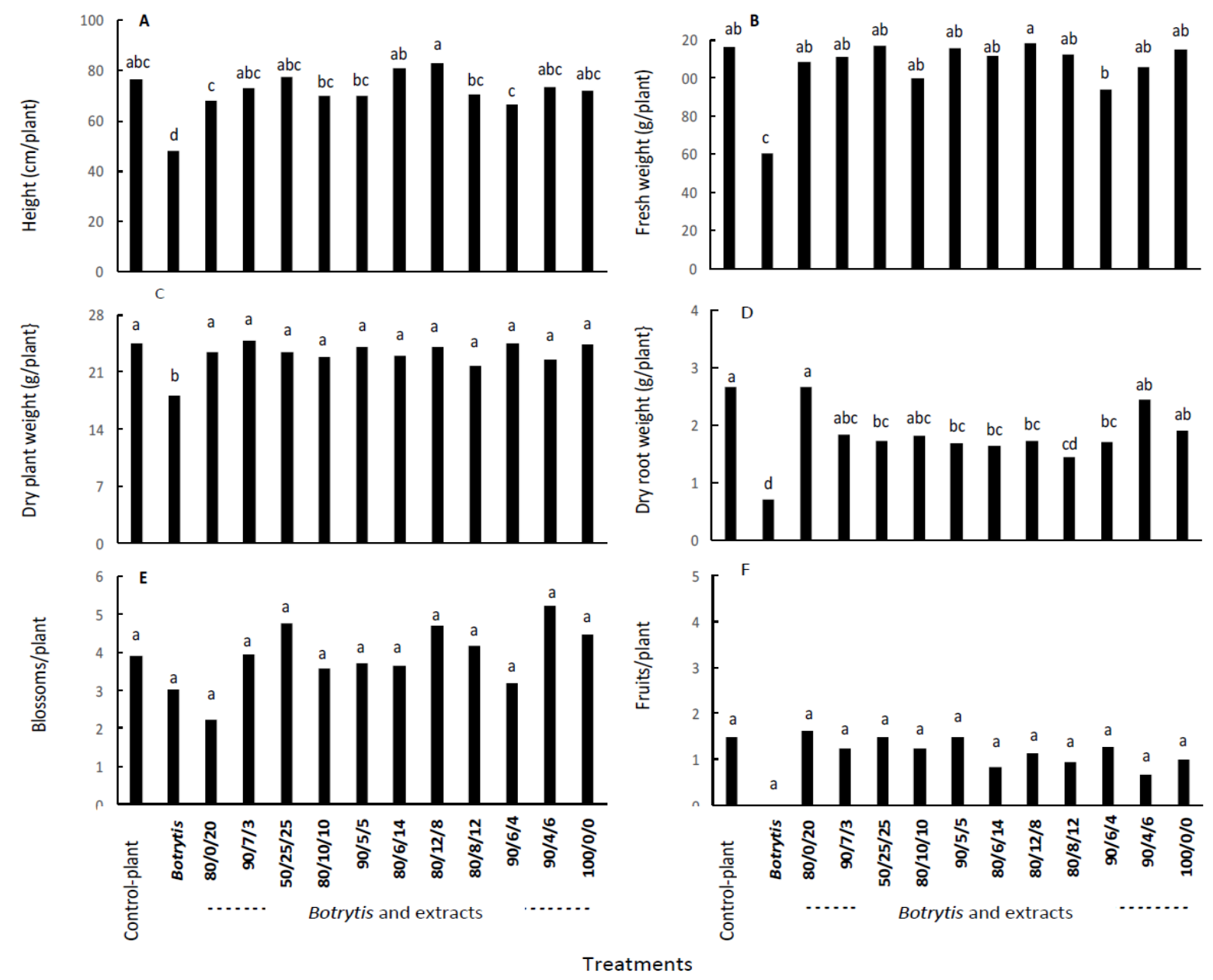

Figure 4. Fresh and dry plant and root weight, plant height, number of flowers and fruits of tomato plants infected with the fungus $B$. cinerea to which different concentrations of olive-pomegranate-orange polyphenolic extracts were applied. 
Regarding the number of blossoms formed on tomato plants, due to the large variability of formed blossoms, there was no statistically important difference among the examined treatments (Figure 4E). Number of flowers in OPO-PE treatment containing 90-4-6, 50-25-25, 80-12-8, $100-0-0$ and $90-7-3$ were slightly higher even than the treatment of the "control-plant" although they did not differ statistically. Likewise, due to the large variability in number of formed tomato fruits/plant, it was observed no statistically significant difference among the examined treatments (Figure 4F). Therefore, polyphenolic extracts can be used to treat $B$. cinerea infestation on tomato plants.

\subsection{Evaluation of the Phytotoxic Effect of Different Concentrations of Olive-Pomegranate-Orange Polyphenolic Extracts on the Growth of Tomato Plants}

The results of the evaluation of the possible phytotoxic activity of the 11 polyphenolic extracts on tomato plants are presented in Figure 5. Results mentioned plant height showed that the average height of the plants treated with
OPO-PE, at a concentration of 80-0-20, 80-12-8, 90-6-4, 90-4-6 and $100-0-0 \%$ were lower than the average height of the tomato plants treated as "control plant" (Figure 5A). In contrast, no statistically significant differences were observed between average height of the tomato plant treated as "control plants" and the average height of the OPO-PE, at a concentration of 90-7-3, 50-25-25, 80-10-10, 90-5-5 and 80-6-14\%.

Regarding, fresh weight of tomato plants treated as "control plant" did not differ statistically from the fresh weight observed on tomato plants treated with OPO-PE, at a concentration of 90-7-3, 50-25-25, 80-10-10, 90-5-5, 80-6-14 and 90-6-4\% (Figure 5B). In contrast, fresh weight of tomato plant treated as "control plants" differed statistically from the average fresh weight observed on OPO-PE, at a concentration of 80-0-20, 80-12-8, 80-8-12, 90-4-6 and $100-0-0 \%$, resulting a possible phytotoxic effect.

The extracts did not cause a significant reduction (phytotoxicity) in the dry weight of the aboveground part of the tomato plants (Figure 5C). In addition, the extracts did not cause a significant reduction in the dry weight of tomato root (Figure 5D).
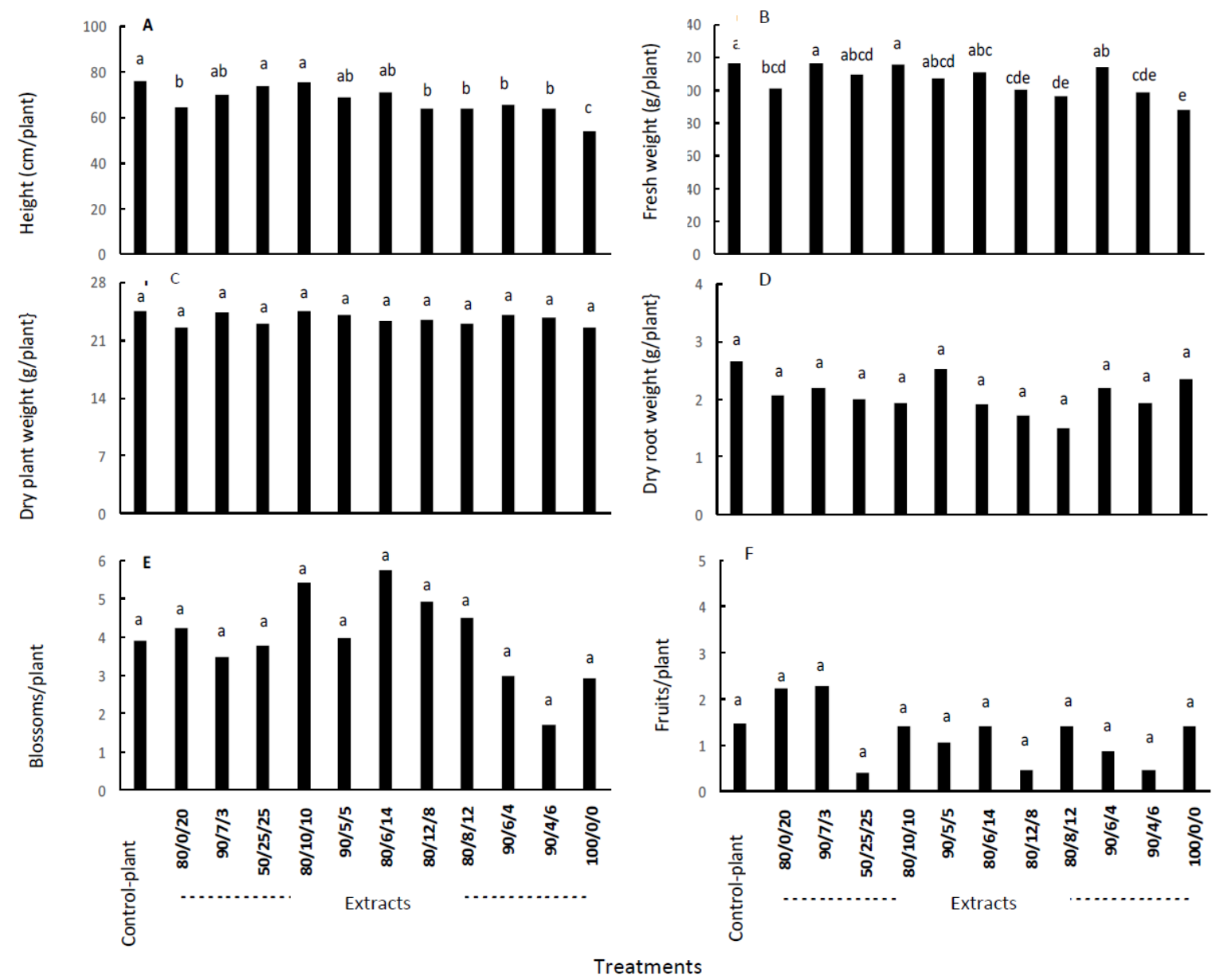

Figure 5. Phytotoxic effect of different concentrations of olive-pomegranate-orange polyphenolic extracts on the growth of tomato plants 
Number of blossoms/plant observed in the examined treatments appeared high variability and thus no statistically important difference was observed (Figure $5 \mathrm{E})$. However, it is worthily to be mentioned that the number of blossoms in the OPO-PE, at a concentration of $80-6-14,80-10-10,80-12-8$ and $80-8-12 \%$ were slightly higher than the number of blossoms observed in "control-plant" treatment. The lowest number of blossoms/plant was observed in the treatments containing OPO-PE, at a concentration of $90-4-6$ and $100-0-0 \%$. Likewise, due to the large variability of number of tomato fruits/plant formed and in this case, it was observed no statistically important difference between examined treatments (Figure 5F).

Therefore, polyphenolic extracts can be applied on tomato plants used in order to treat various phytopathogenic fungi, as long as their phytotoxicity ranges from zero to very low and is offset by the benefit of effective treatment of pathogenic fungi.

Regarding the selection of the most suitable polyphenolic solution that can be used in order to control the 4 phytopathogenic fungi studied in this research project, the following table 3 emerges.

\section{Discussion}

Alternative crop protection methods are based on the use of beneficial microorganisms capable of producing inhibitory bioactive substances against important pests and plant pathogens [53-57]. Natural compounds can be extracted from tissues or from agro-industrial wastes of various plant species. As it was mentioned above, the ongoing challenge is to protect plant production and consequently food production with natural antimicrobials to prevent degradation, especially during plat production and fruit storage and / or processing. This situation creates the need to find solutions that lead to maintaining the quality of plant products. In a recent study, van Long et al., [58] studied the effect of essential oils, preservatives, natural products, chemical fungicides, and coated nanoparticles in vitro and in vivo on different membranes to extend shelf life of fresh fruits and vegetables while many other studies have mentioned the potential use of medicinal plants as biological crop protection agents [27].

Table 3. Evaluation of polyphenolic extract of olive-pomegranate and orange wastes used as bio-chemical agent against important phytopathogenic fungi on tomato cultivation

\begin{tabular}{|c|c|c|c|c|}
\hline $\begin{array}{c}\text { Polyphenolic extract } \\
\text { Olive-Pomegranate-Orange }\end{array}$ & $\begin{array}{c}\text { Pyrenochaeta } \\
\text { lycopersici }\end{array}$ & Rhizoctonia solani & Vreticillium dahliae & $\begin{array}{l}\text { Botrytis } \\
\text { cinerea }\end{array}$ \\
\hline $80-0-20$ & - & - & - & - \\
\hline $90-7-3$ & - & - & - & - \\
\hline $50-25-25$ & - & - & - & $\mathrm{x}$ \\
\hline $80-10-10$ & - & - & - & \\
\hline $90-5-5$ & $\mathrm{x}$ & - & - & $\mathrm{x}$ \\
\hline $80-6-14$ & - & $\mathrm{x}$ & - & \\
\hline $80-12-8$ & $\mathrm{x}$ & $\mathrm{x}$ & $\mathrm{x}$ & $\mathrm{x}$ \\
\hline $80-8-12$ & $\mathrm{x}$ & - & - & \\
\hline $90-6-4$ & - & - & - & $\mathrm{x}$ \\
\hline $90-4-6$ & $\mathrm{x}$ & - & $\mathrm{x}$ & \\
\hline $100-0-0$ & $\mathrm{x}$ & - & - & $\mathrm{x}$ \\
\hline
\end{tabular}


During the process of juicing, large amounts of bark and seeds (which make up about $50 \%$ of the total weight) are discarded as waste [59]. Pomegranate residues of juicing industry it has been calculated that although pomegranate peel is amounted about $24 \%$ of the fruit, it can be responsible for the $40-50 \%$ of its total weight [60]. Disposal of these solid wastes cause serious environmental problems. Thus, further treatment is needed. So far many efforts have been completed in order to use these wastes. Quagli et al., [61] studied the influence of pomegranate fruit tissues and liquid waste mills against phytopathogenic fungi such as Alternaria, Aspergillus, Botrytis, Colletotrichum, Coniella, Nematospora, Penicillium, Pestahlopus Syphance and Sphaidi, Pilidi concluding that compounds included in these wastes may appear antifungal activity. Furthermore, according to Rosas-Burgos et al., [62] the untreated methanolic extracts of the sweet and sour varieties of pomegranate peel showed significant inhibition of fungi $A$. flavus, $F$. verticillioides, A. alternata and B. cinerea. Another study, completed by Elsherbiny et al., [63] investigated the efficacy of methanol extract from pomegranate peels to control the growth of $F$. sambucinum. In in vivo experiments, methanol extract from pomegranate peels results a significant reduction in the development of the disease in potato tubers suggesting that this extract could be used as an alternative plant protection agent to control dry rot in potato tubers. Furthermore, Tayel et al., [64] documented in his study that extracts of solid pomegranate juice residues can also be used for plant protection applications. In particular, the above author used pomegranate extracts as an alternative, low-risk, antifungal preparation for the treatment of green mold $(P$. digitatum) in orange fruits suggesting that they can be used as natural antifungals to disinfect orange storage chambers and to disinfect the fruit itself by immersing it in an aqueous solution. Similar study has been completed by Tehranifar et al., [60] who studied the antioxidant and antifungal properties of pomegranate peels and extracts against Penicillium italicum, Rhizopus stolonifer and B. cinerea that cause post-harvest fruit rot. The results of their study concluded that the peels and extracts of the seeds had a greater inhibitory effect than the extract of the leaves. Similarly, Glazer et al., [65] studied the antifungal action of solid pomegranate juice residue extracts on a number of known phytopathogenic fungi responsible for spoiling fruits and vegetables during their storage and specifically against $A$. alternata, Stemphylium botryosum, and Fusarium spp. The use of pomegranate peel extract (PGE) has been also shown to be very effective in inhibiting the growth of fungi after artificial vaccinations in lemon, grapefruit and apples by $P$. digitatum and $P$. italicum, [66] playing an important role in plant protection actions [67].

Regarding the use of OMWW, it is well known that OMWW are the main pollutant parameter responsible for the severe environmental impact of wastewater mills especially in the Mediterranean countries. However, several research studies have demonstrated the potential use of these compounds as environmental friendly plant protective method applied on several plant species producing fruits, vegetables and flowers during the growing season and postharvest period under storage conditions [68-71]. Furthermore, Kotsou et al., [72] reported that OMWW shown antifungal action against $R$. solani in field experiments while Mavrakis, [73] also reported that various forms of OMWW polyphenols and especially the liquid one affect the development of several important plant pathogenic fungi such as $B$. cinerea, $A$. alternata, $F$. oxysporum f.sp., melonis, Rhizopus species, C. higginsianum, and P. parasitica var. nicotianae, Despite their antimicrobial activity OMWW wastes can also be used as herbicides since in high concentrations appear phytotoxic effects affecting seed germination [74]. However, this attribute may limit their application in cultivated plant species.

Citrus fruits are the most abundant fruit crop in the world, with annual production estimated from 110-125 million tons [75]. Oranges are the fruit produced in the largest proportion of all citrus fruits (70.6 tsp), about 33\% of total production is subjected to industrial processing, resulting in the creation of about 15 e.t. waste, which corresponds to $50 \%$ of the initial mass of the processed fruits. Their use is necessary, both to avoid environmental pollution and because the value of the by-products that can be produced from them is important. Despite their use as bioactive extracts and food ingredients, it is believed that these wastes can be also applied as organic fertilizer and plant protective compounds suppressing damage caused by pest and diseases [76-78]. According to De Corato, [79] in a study completed by Bernal-Vicente et al., $[80]$ it was commented that composted citrus fruit residues have shown slight increasing of total biomass in a melon cropping system cultivated under greenhouse nurseries, due to bioactive action of auxin-like and cytokine-like molecules.

Small size of the olive mills have resulted in a difficulty in utilization of liquid wastes. However, the potential of their use as well as the limited industries that are involved in the production-extraction of polyphenolic components from various sources makes it particularly encouraging. The utilization of all quantities of liquid wastes produced, except for technological difficulties, requires the promotion of policies to encourage and develop a National Action Plan for olive mill wastes. Further research is recommended on the acceptance of these products by consumers, as well as the benefits arising from their use as new organic plant protection products and fertilizers in order to increase their dissemination. Technologies that utilize liquid mill wastes and extract their polyphenolic components also need to be improved. In particular, in vitro evaluation of different phytopathogenic species is 
recommended while test panels can be used in order to evaluate the taste of the products to which these polyphenolic extracts have been applied in food industry. Concluding, as it is suggested by Dávila et al., [81], by improving isolation, marketing and use of compounds presented in plant residues that have high bioactivity may be the way to better use and utilize these residues. This can lead to independence on agrochemicals used in crop production.

\section{Conclusions}

The findings of this study demonstrate the potential activity of aqueous extracts of olive-pomegranate-orange fruits isolated by microwave assisted extraction. Especially, these polyphenolic compounds could protect tomato plants from fungi infections and provide adequate tomato growth and yield. Form previous work it demonstrated that the fungi P. lycopersici, $R$. solani, $V$. dahliae and $B$. cinerea showed growth sensitivity at the tested extracts. Based on these results it is understood that the use of the tested extracts might be an alternative, bio-control method of plant diseases caused by these pathogens. From the above it is clear that the olive fruit polyphenol extract, combined with pomegranate and orange extracts, has presented encouraging results, but the effectiveness should be studied further.

\section{Acknowledgments}

This research has been co - financed by the European Regional Development Fund of the European Union and Greek National funds through the Operational Program Competitiveness, Entrepreneurship and Innovation, under the call RESEARCH - CREATE - INNOVATE (Project code:T1EDK-03942). Also, Benaki Phytopathological Institute is acknowledged for offering plant pathogenic microorganisms.

\section{Author Contributions}

S.L., conducted the experiments and wrote the manuscript. C.P., conducted the experiments. I.V., reviewed the manuscript and conducted the data analysis, K.P., supervised the experiments. All authors have read and agreed to the published version of the manuscript.

\section{Conflicts of Interest}

The authors declare no conflict of interest.

\section{REFERENCES}

[1] Godfray, H.C.J., Beddington, J.R., Crute, I.R., Haddad, L., Lawrence, D., Muir, J.F., Pretty, J., Robinson, S., Thomas, S.M., C., Toulmin, "Food security: the challenge of feeding 9 billion people," Science, vol. 327, pp. 812-818, 2010. DOI: $10.1126 /$ science. 1185383

[2] Savary, S., Willocquet, L., Pethybridge, S.J., Esker, P., McRoberts, N., A., Nelson, "The global burden of pathogens and pests on major food crops," Natural Ecology and Evolution, vol. 3, pp. 430-439, 2019. doi.org/10.1038/s41559-018-0793-y

[3] Crabtree, G.W., M.S., Dresselhaus, "The hydrogen fuel alternative," Mrs Bulletin, vol. 33(4), pp. 421-428, 2008. DOI: https://doi.org/10.1557/mrs2008.84

[4] Leontopoulos, S., Arabatzis, G., Ntanos, S., Ch., Tsiantikoudis, "Acceptance of energy crops by farmers in Larissa's regional unit. A first approach," $7^{\text {th }}$ International Conference on Information and Communication Technologies in Agriculture, Food and Environment (HAICTA), 2015a. Kavala, 17-20/09/15, CEUR Workshop Proceedings vol. 1498, pp. 38-43, 2015a. Corpus ID: 42285213

[5] Kyriakopoulos, G.L., G., Arabatzis, "Electrical energy storage systems in electricity generation: Energy policies, innovative technologies, and regulatory regimes," Renewable and Sustainable Energy Reviews, vol. 56, pp. 1044-1067, 2016. doi.org/10.1016/j.rser.2015.12.046

[6] Sands, R.D., Malcolm, S.A., Suttles, S.A., E., Marshall, "Dedicated energy crops and competition for agricultural land. United States Department of Agriculture (USDA). A report summary from the economic research service," 2017. Available at: www.ers.usda.gov

[7] Anatolioti, V., Leontopoulos, S., Skoufogianni, G., P., Skenderidis, "A study on the potential use of energy crops as alternative cultivation in Greece. Issues of farmer's attitudes," $4^{\text {th }}$ I.C., FaBE 2019, Crete Island 30/05-02/06/19. FaBE Proceedings: $410-445$.

[8] Muri, S.D., van der Voet, H., Boon, P.E., van Klaveren, J.D., B.J., Bróschweiler, "Comparison of human health risks resulting from exposure to fungicides and mycotoxins via food," Food and Chemical Toxicology, vol. 47, pp. 2963-2974, 2009. doi.org/10.1016/j.fct.2009.03.035

[9] Makridis, C., Svarnas, C., Rigas, N., Gougoulias, N., Roka, L., S., Leontopoulos, "Transfer of heavy metal contaminants from animal feed to animal products," Journal of Agricultural Science and Technology, USA, vol. 2(1A), pp. 149-154, 2012.

[10] Gougoulias, N., Leontopoulos, S., Ch., Makridis, "Influence of food allowance in heavy metal's concentration in raw milk production of several feed animals," Emirates Journal of Food and Agriculture, vol. 26(9), pp. 828-834, 2014. DOI: 10.9755/ejfa.v26i9.17382

[11] Leontopoulos, S., Gougoulias, N., Kantas, D., Roka, L., Ch., Makridis, "Heavy metal accumulation in animal tissues and internal organs of pigs correlated with feed habits," Bulgarian Journal of Agricultural Science, vol. 21(3), pp. 693-697, 2015b. Corpus ID: 20873564 
[12] Han, W., Tian, Y., X., Shen, "Human exposure to neonicotinoid insecticides and the evaluation of their potential toxicity: An overview", Chemosphere, vol. 192, pp. 59-65, 2018. doi.org/10.1016/j.chemosphere.2017.10.149

[13] Zhang, Q., Zhu, D., Ding, J., Zheng, F., Zhou, S., Lu, T., Zhu, Y.-G., H., Qian, "The fungicide azoxystrobin perturbs the gut microbiota community and enriches antibiotic resistance genes in Enchytraeus crypticus," Environment International, vol. 131, pp. 104965, 2019. doi.org/10.1016/j.envint.2019.1 04965

[14] Ock, J., Kim, J., Y.-H., Choi, "Organophosphate insecticide exposure and telomere length in U.S. adults," Science of the Total Environment, vol. 709, pp. 135990, 2020. doi.org/10.1016/j.scitotenv.2019.135990

[15] Lai, W.T., Khong, N.M.H., Lim, S.S., Hee, Y.Y., Sim, B.I., Lau, K.Y., O.M., Lai, "A review: Modified agricultural by-products for the development and fortification of food products and nutraceuticals," Trends Food Science Technology, vol. 59, pp. 148-160, 2017. doi.org/10.1016/j.tifs.2016.11.014

[16] Ayala-Zavala, J.F., Vega-Vega, V., Rosas-Domínguez, C., Palafox-Carlos, H., Villa-Rodriguez, J.A., Wasim Siddiqui, Md., Dávila-Aviña, J.E., G.A., González-Aguilar, "Agro-industrial potential of exotic fruit byproducts as a source of food additives," Food Res. Int, vol. 44(7), pp. 1866-1874, 2011. doi.org/10.1016/j.foodres.2011.02.021

[17] Vinha, A.F., Barreira, S.V., Castro, A., Costa, A., M.B.P., Oliveira, "Influence of the storage conditions on the physicochemical properties, antioxidant activity and microbial flora of different tomato (Lycopersicon esculentum L.) cultivars," Journal of Agricultural Science, vol. 5(2), pp. 118, 2013. DOI:10.5539/jas.v5n2p118

[18] Mensah, J.K., D., Golomeke, “Antioxidant and antimicrobial activities of the extracts of the Calyx of Hibiscus sabdariffa," Linn. Current Science Perspectives, vol. 1(2), pp. 69-76, 2015. DOI: 10.5897/AJFS12.099

[19] Mensah, J.K., Kwoseh, C., Banahene, N., Atuilik, S.A., Oppong, D., M., Borigu, "Assessment of the antimicrobial activities of the secondary metabolites produced by pure cultured Trichoderma koningii, Rhizopus stolonifer and Fusarium oxysporum," Current Science Perspectives, vol. 1(3), pp. 96-101, 2015. Corpus ID: 131769520

[20] Petrotos, K., Lampakis, D., Pilidis G., S.V., Leontopoulos, "Production and encapsulation of polyphenols derived from clarifies waste by using a combination of macroporous resins and spray drying," International Journal of Food and Biosystems Engineering, vol. 1(1), pp. 40-50, $2016 \mathrm{~b}$.

[21] Petrotos, K.B., Kokkora, M.I., Gkoutsidis, P.E., S., Leontopoulos, "A comprehensive study on the kinetics of Olive Mill wastewater (OMWW) polyphenols absorption on macroporous resins. Part II. The case of Amperlite FPX66 commercial resin," Desalination and Water Treatment, pp. 1-8, 2016a. DOI: 10.1080/19443994.2015.1 111820

[22] Kokkora, M.I., Petrotos, K.B., Papaioannou, Ch., Gkoutsidis, P.E., Leontopoulos, S.V., P., Vyrlas, "Agronomic and economic implications of using treated olive mill wastewater in maize production," Desalination and Water Treatment, vol. 57(44), pp. 20639-20645, 2016. doi.org/10.1080/19443 994.2016.1153905
[23] Kokkora, M., Vyrlas, P., Papaioannou, Ch., Petrotos, K., Gkoutsidis, P., Leontopoulos, S., Ch., Makridis, "Agricultural use of microfiltered olive mill wastewater: effects on maize production and soil properties," Agriculture and Agricultural Science Procedia, vol. 4, pp. 416-424, 2015. DOI: $10.1016 /$ j.aaspro.2015.03.047

[24] Leontopoulos, S., Skenderidis, P., Anatolioti, V., Kokkora, M., Tsilfoglou, S., Petrotos, K., Vagelas, I., "Antifungal activity of Azadirachta indica aqueous and non-aqueous extracts on Colletotrichum gloeosporioides, Botryodiplodia theobromae and Fusarium solani. A first approach," International Journal of Food and Biosystems Engineering, vol. 6(1): pp. 38-50, 2017.

[25] Skenderidis, P., Lampakis, D., Giavasis, I., Leontopoulos, S., Petrotos K., Hadjichristodoulou, Tsakalof, C., "A. Chemical properties, fatty-acid composition, and antioxidant activity of goji berry (Lycium barbarum L. and Lycium chinense Mill.) fruits," Antioxidant, vol. 8(3), pp. 1-13, 2019. doi: 10.3390/antiox 8030060

[26] Leontopoulos, S., Skenderidis, P., I.K., Vagelas, "Potential use of polyphenolic compounds obtained from Olive Mill Waste Waters on plant pathogens and plant parasitic nematodes," In: Plant Defence: Biological Control, K.G. Ramawat, editor. 2020a. Published by Springer.

[27] Leontopoulos, S., Skenderidis, P., G., Skoufogianni, "Potential use of medicinal plants as biological crop protection agents," Biomedical Journal of Scientific and Technical Research, vol. 25(4), pp. 19320-19324, 2020. DOI:10.26717/BJSTR.2020.25.004231

[28] Wu, A.H., Yu, M.C., Tseng, C-C., M.C., Pike, "Epidemiology of soy exposures and breast cancer risk," British Journal of Cancer, vol. 98, pp. 9-14,2002. doi: 10.1038/sj.bjc. 6604145

[29] Seeram, N.P., Lee, R., D., Heber, "Bioavailability of ellagic acid in pomegranate (Punica granatum L.) juice," Clinica Chimica Acta, vol. 348(1-2), pp. 63-68, 2004. DOI: 10.1016/j.ccen.2004.04.029

[30] Corona, G., Tzounis, X., Assunta Dessi, M., Deiana, M., Debnam, E.S., Visioli, F., J.P.E., Spencer, "The fate of olive oil polyphenols in the gastrointestinal tract: Implications of gastric and colonic microflora-dependent biotransformation," Journal of Free Radical Residues, vol. 40(6), pp. 647-658, 2006. DOI: 10.1080/107157605003730 00

[31] Syed, D.N., Afaq, F., Kweon, M.H., Hadi, N., Bhatia, N., Spiegelman, V.S., H., Mukhtar, "Green tea polyphenol EGCG suppresses cigarette smoke condensate-induced NF-kappaB activation in normal human bronchial epithelial cells," Oncogene, vol. 26, pp. 673-682, 2007. doi.org/10.1038/sj.onc.1209829

[32] Vauzour, D., Vafeiadou, K., Corona, G., Pollard, S.E., Tzounis, X., J.P.E., Spencer, "Champagne wine polyphenols protect primary cortical neurons against Peroxynitrite-induc ed injury," Journal of Agriculture and Food Chemistry, vol. 55(8), pp. 2854-2860, 2007. doi.org/10.1021/jf063304z

[33] Tzounis, X., Vulevic, J., Kuhnle, G.G.C., George, T., Leonczak, J., Gibson, G.R., Kwik-Uribe, C., J.P.E., Spencer, "Flavanol monomer-induced changes to the human faecal microflora," British Journal of Nutrition, vol. 99, pp. 782-792, 2008. DOI: 10.1017/S0007114507853384 
[34] Celik, I., Temur, A., I., Isik, "Hepato protective role and antioxidant capacity of pomegranate (Punica granatum) flowers in fusion against trichloro-acetic acid- exposed in rats," Food and Chemical Toxicology: An International Journal Published for the British Industrial Biological Research Association, vol. 47, pp. 145-149, 2009. DOI: 10.1016/j.fct.2008.10.020

[35] Tzounis, X., Rodriguez-Mateos, A., Vulevic, J., Gibson, G.R., Kwik-Uribe, C., J.P.E., Spencer, "Prebiotic evaluation of cocoa-derived flavanols in healthy humans by using a randomized, controlled, double-blind, crossover intervention study 1-3," American Journal of Clinical Nutrition, vol. 93, pp. 62-72, 2011. doi.org/10.3945/ajen. 110.000075

[36] Tsilfoglou, S., Petrotos, K., Leontopoulos, S., Hadjichristodoulou, C., A., Tsakalof, "A study on the enrichment of olive oil with natural olive fruit polyphenols," International Journal of Food Biosystems Engineering, vol. 5(1), pp. 68-74, 2017.

[37] Leontopoulos, S., Skenderidis, P., Kalorizou, H., K., Petrotos, "Bioactivity potential of polyphenolic compounds in human health and their effectiveness against various food borne and plant pathogens A review," International Journal of Food Biosystems Engineering, vol. 7(1), pp. 1-19, 2017.

[38] Karimi, M., Sadeghi, R., J., Kokini, "Pomegranate as a promising opportunity in medicine and nanotechnology," Trends in Food Science and Technology, vol. 69, pp. 59-73, 2017. doi.org/10.1016/j.tifs.2017.08.019

[39] Skenderidis, P., Mitsagga, C., Giavasis, I., Petrotos, K., Lampakis, D., Leontopoulos, S., Hadjichristodoulou, C., A., Tsakalof, "The in vitro antimicrobial activity assessment of ultrasound assisted Lycium barbarum fruit extracts and pomegranate fruit peels," Journal of Food Measurement and Characterization, vol. 13, pp. 2017-2031, 2019. doi.org/10.1007/s11694-019-00123-6

[40] Grabež, M., Škrbić, R., Stojiljković, M.P., Rudić-Grujić, V., Paunović, M., Arsić, A., Petrović, S., Vučić, V., Mirjanić-Azarić, B., Šavikin, K., Menković, N., Janković, T., N., Vasiljević, "Beneficial effects of pomegranate peel extract on plasma lipid profile, fatty acids levels and blood pressure in patients with diabetes mellitus type-2: A randomized, double-blind, placebo-controlled study," Journal of Functional Foods, vol. 64, pp. 103692, 2020. doi.org/10.1016/j.jff.2019.103692

[41] Skenderidis, P., Petrotos, K., S., Leontopoulos, "Functional properties of goji berry fruit extracts". In: Phytochemicals in Goji Berries (Lycium barbarum) Applications in Functional Foods. Xingqian, Y., editor. 2020. Published by: Taylor and Francis Group LLC. pp. 181-224.

[42] Stagos, D., "Antioxidant activity of polyphenolic plant extracts," Antioxidants, vol. 9, pp. 19, 2020. doi: 10.3390/antiox9010019

[43] Abbasi, I., "Extraction of essential oils from the seeds of pomegranate using organic solvents and supercritical $\mathrm{CO}_{2}$," Journal of American Oil Chemist's Society, vol. 85, pp. 83-89, 2008. doi.org/10.1007/s11746-007-1158-x

[44] Martins, S., Mussatto, S.I., Martínez-Avila, G., Montañez-Saenz, J., Aguilar, C.N., J.A., Teixeira, "Bioactive phenolic compounds: Production and extraction by solid-state fermentation. A review," Biotechnology
Advances, vol. 39, pp. 365-373, 2011.doi.org/10.1016/j.bio techadv.2011.01.008

[45] Pan, Z., Qu, W., Ma, H., Atungulu, G.G., T.H., McHugh, "Continuous and pulsed ultrasound-assisted extractions of antioxidants from pomegranate peel," Ultrasonic Sonochemistry, vol. 18, pp. 1249-1257, 2011. doi.org/10.1016/j.ultsonch.2011.01.005

[46] Veggi, P.C., Martinez, J., M.A.A., Meireles, "Fundamentals of microwave extraction. In: Microwave-assisted extraction for bioactive compounds," Food Engineering Series, pp. 15-52, 2013.

[47] Petrotos, K.B., Lellis, T., Kokkora, M.I., P.E., Gkoutsidis, "Purification of olive mill wastewater using microfiltration membrane technology," Journal of Membrane and Separation Technology, vol. 3, pp. 50-55, 2014. DOI: 10.6000/1929-6037.2014.03.01.5

[48] Skenderidis, P., Mitsagga, C., Giavasis, I., Hadjichristodoulou, C., Leontopoulos, S., Petrotos, K., A., Tsakalof, "Assessment of antimicrobial properties of water and methanol UAE extracts of goji berry fruit and pomegranate fruit peels in vitro," 2017. $3^{\text {rd }}$ I.C., FaBE 2017, Rhodes Island 01-04/06-17. FaBE Proceedings: 541-549.

[49] Carciochi, R.A., D'Alessandro, L.G., Vauchel, P., Rodriguez, M.M., Nolasco, S.M., K., Dimitrov, "Valorization of agrifood by-products by extracting valuable bioactive compounds using green processes," In Grumezescu Alexandru Mihai, Holban Alina Maria (Eds.). Handbook of Food Bioengineering (pp. 191-228). Academic Press Ingredients Extraction by Physicochemical Methods in Food, 2017. ISBN 9780128115213.

[50] Leontopoulos, S., Mitsagga, Ch., Giavasis, I., Papaioannou, Ch., Vasilakoglou, I., K., Petrotos, "Potential synergistic action of liquid olive fruit polyphenol extract with aqueous extracts of solid wastes of pomegranate or/and orange juice industry as organic phyto-protective agents against important plant pathogens - Part 1 (in vitro studies)," Universal Journal of Agricultural Research, vol. 8(6), pp. 202-222, doi.org/10.13189/ujar.2020.080602

[51] Leontopoulos, S.V., Giavasis, I., Petrotos, K., Kokkora, M., Ch., Makridis, "Effect of different formulations of polyphenolic compounds obtained from OMWW on the growth of several fungal plant and food borne pathogens. Studies in vitro and in vivo,' Agriculture and Agricultural Science Procedia, vol. 4, pp. 327-337, 2015. doi.org/10.1016/j.aaspro.2015.03.037

[52] Leontopoulos, S.V., Kokkora, M.I., K.B., Petrotos, "In vivo evaluation of liquid polyphenols obtained from OMWW as natural bio-chemicals against several fungal pathogens on tomato plants," Desalination and Water Treatment, vol. 57(44), pp. 20646-20660, 2016. doi.org/10.1080/19443994. 2016.1154707

[53] Vagelas, I.K., Leontopoulos, S.V., Pembroke, B., S.R., Gowen, "Poisson and negative binomial modeling techniques for better understanding Pasteuria penetrans spore attachment on Root-Knot Nematode juveniles," Journal of Agricultural Science and Technology USA, vol. 2, (2A), pp. 273-277, 2012. Corpus ID: 83402783

[54] Vagelas, I., S., Leontopoulos, "Cross-protection of cotton against Verticillium wilt by Verticillium nigrescens," Emirates journal of Food and Agriculture, vol. 27(9), pp. 
687-691, 2015. DOI: 10.9755/ejfa.2015-04-047

[55] Leontopoulos, S., Petrotos, K., Anatolioti, V., Skenderidis, P., Tsilfoglou, S., I., Vagelas, "Effects of cells and cells-free filtrates supernatant solution of Pseudomonas oryzihabitans on root-knot nematodes (Meloidogyne javanica)," International Journal of Food and Biosystems Engineering, vol. 6(1), pp. 23-37, 2017.

[56] Skoufogianni, G., Anatolioti, V., S., Leontopoulos, "Efficacy of the entomopathogenic bacteria Xenorhabdus nematophilus and Xenorhabdus bovienii on different development stages of Phaedon cochleariae," $4^{\text {th }}$ I.C., FaBE 2019, Crete Island 30/05-02/06/19. FaBE Proceedings: pp. 365-381, 2019.

[57] Tekiner, N., Kotan, R., Tozlu, E., F., Dadaşoğlu, "Biological Control of Coniella granati Saccardo in Pomegranate," Universal Journal of Agricultural Research, vol. 8(1), pp. 18-24, 2020. doi: 10.13189/ujar.2020.080103

[58] van Long, N.N., Joly, C., P., Dantigny, "Active packaging with antifungal activities," International Journal of Food Microbiology, vol. 220, pp. 73-90, 2016.doi.org/10.1016/j.i jfoodmicro.2016.01.001

[59] Ruales, J., Baenas, N., Moreno, D.A., Stinco, C.M., Meléndez-Martínez, A.J. A., García-Ruiz, "Biological active Ecuadorian mango 'Tommy Atkins' Ingredients-An opportunity to reduce agrowaste," Nutrients, vol. 10(9), pp. 1138, 2018. doi: 10.3390/nu10091138

[60] Tehranifar, A., Selahvarzi, Y., Kharrazi, M., V.J., Bakhsh, "High potential of agro-industrial by-products of pomegranate (Punica granatum L.) as the powerful antifungal and antioxidant substances," Industrial Crops Products, vol. 34(3), pp. 1523-1527, 2011. doi.org/10.1016/ j.indcrop.2011.05.007

[61] Quagli, M., Moretti, C., Cerri, M., Linoci, G., Cappelletti, G., Urbani, S., A., Taticchi, "Effect of extracts of wastewater from olive milling in postharvest treatments of pomegranate fruit decay caused by Penicillium adametzioides," Postharvest Biology and Technology, vol. 118, pp. 26-34, 2016. doi.org/10.1016/j.postharvbio.2016.03.012

[62] Rosas-Burgos, A., Burgos-Hernandez, A., Noguera-Artiaga, L., Kacaniova, M., Hernandez-Garcia, F., Cardenas-Lopez, J.L., A.A., Carbonell-Barrachina, "Antimicrobial activity of pomegranate peel extracts as affected by cultivar," Journal of Science of Food Agriculture, vol. 97, pp. 802-810, 2017. DOI: $10.1002 /$ jsfa.7799

[63] Elsherbiny, A., Amin, B.H., Z.A., Baka, "Efficiency of pomegranate (Punica granatum L.) peels extract as a high potential natural tool towards Fusarium dry rot on potato tubers Elsherbiny," Posthurvest Biology and. Technology, vol. 111, pp. 256-263, 2016. DOI: 10.1016/j.postharvbio.20 15.09.019

[64] Tayel, A.A., W.F., El-Trasm, "Anticandidal activity of pomegranate peel extract aerosol as an applicable sanitizing method," Mycoses, vol. 53(2), pp. 117-122, 2009. DOI: 10.1111/j.1439-0507.2008.01681.x

[65] Glazer, I., Masaphy, S., Marciano, P., Bar-Ilan, I., Holland, D., Kerem, Z., R., Amir, "Partial identification of antifungal compounds from Punica granatum peel extracts," Journal of Agriculture and Food Chemistry, vol. 60, pp. 4841-4848,

\section{DOI: $10.1021 / j f 300330 y$}

[66] Li Destri Nicosia, MG., Pangallo, S., Raphael, G., Romeo, F.V., Strano, M.C., Rapisard, P., Droby, S., L., Schena, "Control of postharvest fungal rots on citrus fruit and sweet cherries using a pomegranate peel extract," Postharvest Biology and Technology, vol. 114, pp. 54-61, 2016. doi.org/10.1016/j.postharvbio.2015.11.012

[67] Endo, E.H., Cortez, D.A.G., Ueda-Nakamura, T., Nakamura, C.V., B.P.D., Filho, "Potent antifungal activity of extracts and pure compound isolated from pomegranate peels and synergism with fluconazole against Candida albicans," Residual Microbiology, vol. 161, pp. 534-540, 2010. DOI: 10.1016/j.resmic.2010.05.002

[68] Bonanomi, G., Giorgi, V., Del Sorbo, G., Neri, D., F., Scala, "Olive mill residues affect saprophytic growth and disease incidence of foliar and soilborne plant fungal pathogens," Agriculture Ecosystems and Environment, vol. 115, pp. 194-200, 2006. doi.org/10.1016/j.agee.2006.01.002

[69] Vagelas, I., Papachatzis, A., Kalorizou, H., E., Wogiatzi, "Biological control of Botrytis fruit rot (gray mold) on strawberry and red pepper fruits by olive oil mill wastewater," Biotechnology and. Biotechnological Equipments, vol. 23(4), pp. 1489-1491, 2009. doi.org/10.2478/V10133-009-0 $017-3$

[70] Vagelas, I., Kalorizou, H., Papachatzis, A., M., Botu, "Bioactivity of olive oil mill wastewater against plant pathogens and post-harvest diseases," Biotechnology and Biotechnological Equipments, vol. 23(2), pp. 1217-1219, 2009. doi.org/10.1080/13102818.2009.10817641

[71] Lykas, C., Vagelas, I., N., Gougoulias, "Effect of olive mill wastewater on growth and bulb production of tulip plants infected by bulb diseases," Spanish Journal of Agricultural Residues, vol. 2, pp. 233, 2014. DOI: 10.5424/sjar/2014121 $-4662$

[72] Kotsou, M., Mari, I., Lasaridi, K., Chatzipavlidis, I., Balis, C., A., Kyriacou, "The effect of olive oil mill wastewater (OMW) on soil microbial communities and suppressiveness against Rhizoctonia solani," Applied Soil Ecology, vol. 26, pp. 113-121, 2004. doi.org/10.1016/j.apsoil.2003.12.001

[73] Mavrakis, N., "Exploitation of bioactive constituents of olive leaves, grape pomace, olive mill waste water and their application in phytoprotection," 2009: Ph.D THESIS, Cranfield University.

[74] Martin, J., Sampedro, I., Garcia-Romera, I., Garcia-Garrido, J.M., J.A., Ocampo, "Arbuscular mycorrhizal colonization and growth of soybean (Glycine max) and lettuce (Lactuca sativa) and phytotoxic effects of olive mill residues," Soil Biology and Biochemistry, vol. 34, pp. 1769-1775, 2002. doi.org/10.1016/S0038-0717(02)00164-5

[75] Mahato, N., Sharma, K., Sinha, M., Baral, E.R., Koteswararao, R., Dhyani, A., Cho, M.H., S., Cho, "Bio-sorbents, industrially important chemicals and novel materials from citrus processing waste as a sustainable and renewable bioresource: A review," Journal of Advanced Residues, vol. 23, pp. 61-82, 2020. doi.org/10.1016/j.jare.2 020.01 .007

[76] Plaza, P., Torres, R., Usall, J., Lamarca, N., I., Vinas, "Evaluation of the potentialof commercial post-harvest 
of Solid Wastes of Pomegranate or/ and Orange Juice Against Important Plant Pathogens - Part 2 (in vivo studies)

application of essential oils to control citrus decay," Journal of Horticultural Science and Biotechnology, vol. 79(6), pp. 935-940, 2004. doi.org/10.1080/14620316.2004.11511869

[77] Stevic, T., Beric, T., Savikin, K., Sokovic, M., Godevac, D., Dimkic, I., S., Stankovic, "Antifungal activity of selected essential oils against fungi isolatedfrom medicinal plant," Industrial Crops Products, vol. 55, pp.116-122, 2014. doi.org/10.1016/j.indcrop.2014.02.011

[78] Campolo, O., Puglisi, I., Barbagallo, R.N., Cherif, A., Ricupero, M., Biondi, A., Palmeri, V., Baglieri, A., L., Zappal, "Side effects of two citrus essential oil formulations on a generalist insect predator, plant and soil enzymatic activities," Chemosphere, vol. 257, pp. 127252, 2020. doi.org/10.1016/j.chemosphere.2020.127252

[79] De Corato, U., "Agricultural waste recycling in horticultural intensive farming systems by on-farm composting and compost-based tea application improves soil quality and plant health: A review under the perspective of a circular economy," Science of Total Environment, vol. 738, pp. 139840, 2020. doi.org/10.1016/j.scitotenv.2020.139840

[80] Bernal-Vicente, A., Ros, M., Tittarelli, F., Intrigliolo, F., J.A., Pascual, "Citrus compost and its water extract for cultivation of melon plants in green house nurseries. Evaluation of nutritive and biocontrol effects," Bioresource Technology, vol. 99(18), pp. 8722-8728, 2008. DOI: 10.1016/j.biortech.2008.04.019

[81] Dávila, J.A., Rosenberg, M., Castro, E., C.A., Cardona, "A model biorefinery for avocado (Persea americana Mill.)," Procedure of Bioresource Technology, vol. 243, pp. 17-29, 2017. doi.org/10.1016/j.biortech.2017.06.063 